\title{
Research for the internet generation: millenialls and centenialls
}

La investigación para la generación del internet: milenialls y centenialls

Cruz Xiomara Peraza de Aparicio

Master, Metropolitan University of Ecuador. Teacher Enfermeria, Guayaquil, Ecuador cperaza@umet.edu.ec. https://orcid.org/oooo-0003-2588-970X

\begin{abstract}
Research is one of the key processes of university management, which is facing a complex situation as a result of the health crisis, exacerbated by the digital and generational gap in terms of the approach to virtual scenarios. The Objective: to determine the impact of technological digitalization and the generation gap on university research. Methodology: a documentary research was carried out by means of a bibliographic review of scientific articles taken from Latindex, Redalyc, SciELO, electronic books, documents from official organizations. Results: The university of this century should be dominated by science and technology with the participation of all its researchers. The levels of digital divide: access, use and appropriation of ICT by individuals and organizations (public or private), delay the use of these technologies. The analysis is complex and hinders the development of strategies that allow an adequate management of the generations at work and Conclusions: The challenge for teachers is even greater when being aware that they are working with students born in the digital era, and therefore are constantly receptive to all kinds of innovations.
\end{abstract}




\section{Resumen}

La investigación constituye uno de los procesos claves de la gestión universitaria, la cual afronta una situación compleja, producto de la crisis sanitaria, exacerbada por la brecha digital y generacional en cuanto al abordaje de los escenarios virtuales. El Objetivo: precisar como impactan en la investigación universitaria la digitalización tecnológica y la brecha generacional. La Metodología: se realizó una investigación documental, mediante la revisión bibliográfica de artículos científicos tomados de Latindex, Redalyc, SciELO, libros electrónicos, documentos de organismos oficiales. Resultados: La universidad de este siglo debe estar dominada por la ciencia y la tecnología con la participación de todos sus investigadores. Los niveles de brecha digital: acceso, uso y apropiación de TIC por individuos y organizaciones (públicas o privadas), retrasan el aprovechamiento de estas tecnologías. Es complejo el análisis y dificulta el desarrollo de estrategias que permitan una adecuada gestión de las generaciones en el trabajo y Conclusiones: El reto para el docente es aún mayor al estar conscientes de que se está trabajando con estudiantes nacidos en la era digital, y por lo tanto se muestran constantemente receptivos a todo tipo de innovaciones.

\section{Palabras clave/ Keywords}

Research, digital divide, generational divide, Technologies

Investigación, brecha digital, brecha generacional, Tecnologías

\section{Introduction}

In the 21 st century, the complexity of the world's problems is undeniable and constitutes a challenge to be solved by universities, for which challenges and opportunities must be taken into account. (Rivera, Espinosa, \& Valdés, 2017), point out that the university is the most appropriate place to promote scientific activity, since it makes it possible for the faculty to keep in touch with the international flow of knowledge, through the processes of internationalization.

The university of this century must be dominated by science and technology with the participation of all its researchers. One of the characteristics of the university in the 21 st century is the recomposition of its current role in 
society. This will be more promising if it is produced as part of the understanding, analysis, proposals and academic consensus on its role and objectives in the current globalized world, without forgetting that scientific knowledge aims to understand how nature is structured and functions, but the contexts for its generation have been diverse, which contain situations related to the human race, health conditions, the effects of climate change, the arrival of Artificial Intelligence with its pros and cons, among other multiple factors that complicate this role facing universities at this time.

The incorporation of ICTs in education has opened up great possibilities for improving teaching and learning processes. However, it is not enough to equip educational centers with computers. ( Carneiro, \& Díaz, 2021) refer that, at the same time, it is necessary to address a change in the organization of schools and educational institutions and in the digital competencies of teachers.

Regarding the substantive processes, specifically in the case of research in higher education through the use of ICTs, ( Licona \& Veytia, 2019), ( Licona \& Veytia, 2019), refer to a field that is beginning to take off and that is constantly advancing in terms of its study. Veytia, 2019), refer is a field that is beginning to take apogee and that is in constant progress in terms of its study, because although it is true that the investigations referred to research or use of ICT have been gaining presence, the study of these focused on higher education and specifically for the development of training in and for research is just gaining strength, therefore, that in universities is seen as a priority the development of these in their future graduates, to enable the development of a comprehensive training.

However, as a result of the health emergency, in March 2020, the Metropolitan University abruptly switched from face-to-face to virtuality, measures were taken to maintain the substantive processes in force within the indications of the Ministry of Public Health and the agencies responsible for public safety, the confinement of the Ecuadorian population was indicated, the university took emergency measures and in less than a month teachers and students were already using virtuality.

For the other substantive processes represented in the linkage and research projects, they designed strategies oriented to the development of virtual activities, which have been fulfilled with the induction of students towards the writing of scientific production to compensate and maintain the projects in progress, and these productions have been taken virtually to congresses, symposiums, national and international conferences. 
All the aforementioned evidenced the need to train and update teachers in the area of ICTs for the early mastery of Moodle and Teams platforms, among others, for the teaching of classes, evidencing clearly the digital and generational gap in terms of ICT management by teachers, Many of them belonging to the silent generation, the boom generation and generation $\mathrm{X}$, accepted the challenge and prompt adaptation to meet the demands of the university in terms of compliance with the substantive processes.

This situation coincides with that described by (Enriquez \& Saenz, 2021). with what millions of students returned home and have had to face a scenario for which the educational systems were not prepared, if it is taken into account that by 2017 , the percentage of households with access to information and communication technologies in the subregion was $34.9 \%(52.2 \%$ in Latin America and the Caribbean) and the percentage of households with computers was $29.8 \%$ (44.7\% in Latin America and the Caribbean).Due to the importance of the topic the objective of the research to specify how technological digitization and the generation gap impact on university research.

\section{Materials and Methods}

In the 21 st century, the complexity of the world's problems is undeniable and constitutes a challenge to be solved by universities, for which challenges and opportunities must be taken into account. (Rivera, Espinosa, \& Valdés, 2017), point out that the university is the most appropriate place to promote scientific activity, since it makes it possible for the faculty to keep in touch with the international flow of knowledge, through the processes of internationalization.

The university of this century must be dominated by science and technology with the participation of all its researchers. One of the characteristics of the university in the 21 st century is the recomposition of its current role in society. This will be more promising if it is produced as part of the understanding, analysis, proposals and academic consensus on its role and objectives in the current globalized world, without forgetting that scientific knowledge aims to understand how nature is structured and functions, but the contexts for its generation have been diverse, which contain situations related to the human race, health conditions, the effects of climate change, the arrival of Artificial Intelligence with its pros and cons, among other multiple factors that complicate this role facing universities at this time.

The incorporation of ICTs in education has opened up great possibilities for improving teaching and learning processes. However, it is not enough to 
equip educational centers with computers. ( Carneiro, Toscano, \& Díaz, 2021) refer that, at the same time, it is necessary to address a change in the organization of schools and educational institutions and in the digital competencies of teachers.

In terms of substantive processes, specifically in the case of research in higher education through the use of ICTs, ( Licona \& Veytia, 2019), it is a field that is beginning to take off and is constantly advancing in terms of its study. Veytia , 2019), refer is a field that is beginning to take apogee and that is in constant progress in terms of its study, because although it is true that the investigations referred to research or use of ICT have been gaining presence, the study of these focused on higher education and specifically for the development of training in and for research is just gaining strength, therefore, that in universities is seen as a priority the development of these in their future graduates, to enable the development of a comprehensive training.

However, as a result of the health emergency, in March 2020, the Metropolitan University abruptly switched from face-to-face to virtuality, measures were taken to maintain the substantive processes in force within the indications of the Ministry of Public Health and the agencies responsible for public safety, the confinement of the Ecuadorian population was indicated, the university took emergency measures and in less than a month teachers and students were already using virtuality.

For the other substantive processes represented in the linkage and research projects, they designed strategies oriented to the development of virtual activities, which have been fulfilled with the induction of students towards the writing of scientific production to compensate and maintain the projects in progress, and these productions have been taken virtually to congresses, symposiums, national and international conferences.

All the aforementioned evidenced the need to train and update teachers in the area of ICTs for the early mastery of Moodle and Teams platforms, among others, for the teaching of classes, evidencing clearly the digital and generational gap in terms of ICT management by teachers, Many of them belonging to the silent generation, the boom generation and generation $\mathrm{X}$, accepted the challenge and prompt adaptation to meet the demands of the university in terms of compliance with the substantive processes.

This situation coincides with what was described by (Enriquez \& Saenz, 2021). with what millions of students returned home and have had to face a scenario for which the educational systems were not prepared, if it is taken into account that by 2017 , the percentage of households with access to 
information and communication technologies in the subregion was $34.9 \%$ (52.2\% in Latin America and the Caribbean) and the percentage of households with computers was $29.8 \%$ (44.7\% in Latin America and the Caribbean).Due to the importance of the topic the objective of the research to specify how technological digitization and the generation gap impact on university research.

\section{Results}

Educational institutions focus their processes on teaching, research and extension, these are dedicated to the continuous improvement of such processes, to ensure every day their efficiency, effectiveness and organizational performance ( Franco, 2017). The university substantive functions are key in the analysis of the quality processes of the university and the success of these will depend on the management that exists in the same and must respond both to the fulfillment of its strategic objectives and the improvement of the quality and its management (Samá \& Cruz, 2018).

These substantive processes, according to (Aguiar \& Baute, 2020) also referred to as key or main, will have a significant impact on the strategic objectives and are critical to the success of the organization, in addition to being the ones that add value. For this reason, it is of vital importance, in these organizations, to be able to develop, more and more intentionally, the management of their substantive processes, through planning, organization, execution and control, (Alvarez \& Sierra, 2002) (Ortiz, Pérez, \& Velázquez, 2015), in order to obtain superior results with the objective of achieving excellence and the satisfaction of society.

Universities refer Matos \& Cruz, (2017), are being called to assume an integrative posture of their research processes, as a praxeological concretion of the processes of academic training and social management of knowledge, because only in this way will it be possible to train professionals who are able to generate solutions to social problems in the shortest possible time, with relevance and impact, in addition to achieving an optimization of the resources used to achieve these solutions.

The scientific-technical development in contemporaneity, refers (Herrera, 2018), configures a new investigative thinking. From this point of view, quantitative approaches are accompanied by phenomenological comprehensions for the explanation of processes. While qualitative research involves quantitative resources and techniques for measurement and explanation. One of the problems faced by researchers when organizing a 
research process is to select a methodology that is pertinent to the nature of the object/subject of study.

Regarding the construction of knowledge, (Martínez \& Ríos, 2006) point out the coexistence of four fundamental elements in its construction: the subject who knows, the object of knowledge, the operation of knowing and the result obtained from this process. It is an approach to knowing derived from the permanent interaction of various factors that, in an articulated manner, allow access to reality, signify it and give it meaning. However, comments (Romero, 2017) in higher education schools, and mainly in teacher training, reflective, analytical and especially critical subjects are apparently formed, but as in the programs the absence of a theoretical rationality is evident, the referents with which the students' consciousness operates are fenced and they reproduce the content clippings they read and at the same time they appropriate the interpretations made by the professors who coordinate the courses of the different formative trajectories.

In the words of (Skolimowski, 2016) this definition of knowing is linked to various ways of constructing the world, ways that involve apprehending, contemplating and grasping the universe from the dimensions of the spiral of understanding. For these authors, depending on the relationship established between the aforementioned elements, one can arrive at a non-scientific knowledge (based on intuition and sensible grasping) and a scientific understanding (which assumes elements in relation to the contents of the sciences and their method).

Today in education Perez 2018, (Gonzalez, 2021), there is talk about the transition from information technology (ICT) to learning technologies and knowledge (TAC), this technological advancement that covers education, gives added value to the pedagogical in the process of comprehensive academic training, since it promotes and encourages the use of digital didactics in the educational environment generating greater interactivity in the classroom and achieve better learning, for this it is necessary training and continuing education for teachers on the rapid technological changes that arise in the world of technology.

Humanity has evolved through five techno-economic paradigms (Pérez, 2004) has evolved through five techno-economic paradigms 1) the Industrial Revolution (1771); 2) the age of steam and railroads (1829); 3) the age of steel, electricity and heavy engineering (1875); 4) the age of oil, automobiles and mass production (1908); and finally, 5) the age of information technology and telecommunications (1971). In the latter, Information and 
Communication Technologies (ict) have been the central element in the development of the world economy.

Since the 1990s, according to (Domínguez \& Xalabarder, 1997), information technologies have been the relational medium of today's social and economic structures. As a result of the vertiginous development of telecommunications, the space/time relationship has changed radically, but not only has real space diminished, in relative terms, but also a virtual space in constant transformation has emerged from it, the so-called cyberspace.

The Internet had a military origin and, although it may seem contradictory, it was designed without any nerve center, so that communications could never be interrupted. Very soon it began to be used in the academic world: the advantages and improvements in the communication of US universities offered by the network favored a rapid development of its infrastructure, with the massive use of its services by the academic community. And in a few years the constant development and the extension of the cable throughout the planet have allowed an exponential increase in the number of users connected to the network ( Domínguez \& Xalabarder, 1997) ICTs offer numerous advantages: greater access to information, cost reduction in the labor sector, greater connectivity between people, among others. But digitalization, according to (IBERDROLA, 2021) is not taking place equally throughout the world and, in this area too, there is an imbalance and it is known as the digital divide.

They have been identified according to (Cañón, Grande de Prado , \& Cantón, 2016) ( Gómez et al, 2018), (Tablado, 2021) three main levels of digital divide: access, use and appropriation of ICT by individuals and organizations (public or private), which delay the use of these technologies. Similarly regarding the stages of the technology appropriation process, according to ( Sandia, Luzardo, \& Aguilar-Jiménez, 2019). (Van Dijk \& Van Deursen, 2014), refers to 4 stages, among them: 1) motivational access related to the interest and attraction for the new technology, which can be explained by social, cultural, mental and psychological factors; 2) physical or material access linked to the availability of hardware, software, applications, networks and the use of ict and its applications; 3 ) access to digital literacy linked to education to acquire digital skills; and 4) use referred to the significant opportunities for use.

Although the phenomenon of generations has been the subject of study for decades by various authors and disciplines, according to (Díaz-Sarmiento, López-Lambraño, \& Roncallo-Lafont, , 2017) there is no consensus on its definition, determining elements or behaviors associated with generational 
groups. This makes their analysis more complex and hinders the development of strategies that allow an adequate management of generations at work.

All the changes that occur in the world influence the different generations to act in a unique way. Important world events, technological advances, family upbringing, changes in educational and business institutions, make people change the way they face life, the way they dress, the way they communicate, their goals and even their internal values.

According to Ricoveri, cited by (Morey, 2016) he defines the latest generational divisions as follows:

"The Silent Generation, is the one born between 1925 and 1945, the youngest are over 50 years old, however, it is important to know that many married at an early age....".

Women of this generation and also more than a few men hate being and feeling old. The first surgeries performed 20 years ago were weakly accepted by many of this generation with feelings of guilt and fear of social sanction. Many of these interventions had to be repaired today. They were children of marriages that, despite little love, made it last until death. According to (Beckhard, 2007) their parents were the last generation in which the majority served in the military and had great respect for it. This generation retained a high respect for formal authority and for the effectiveness of the command model. Everything changed with their children, the baby-boom generation.

"The BOOM Generation, born between 1946 and 1964, are considered the most oppressive generation in history, considering that they went through the hippie era and disco music; they invented many of the drugs in common use. Now they are the directors of companies where smoking is only allowed in a restricted area...".

This is the Baby Boom generation, because of the large number of births registered in England, Europe and America in general. Many of them are "children of the postwar period". Deeply proud, they tend to feel wise just for being older, refers to the fact that this generation witnessed the vulnerability of authority. (Beckhard, 2007) that this generation witnessed the vulnerability of authority. They witnessed the failure of the Vietnam war, the assassination of the two Kennedys and Martin Luther King, the fall of a president due to Watergate, the OPEC oil crisis, among others.

Unlike their parents, they thought it was reasonable to confront authority directly. In their university life they were marked by taking control of the 
administrative offices as a way of protest, in this generation the value of independence was emphasized from childhood and in this same period of the sixties the contraceptive pill was born, giving women a greater sense of control, this together with the incorporation of women into the working world ended up reinforcing this feeling of self-worth and control.

"Generation X, born between 1965 and 1981, with much more acceptance for diversity of races, creeds and tendencies, see life in a much more cynical way, as they have grown up in times where danger can be found around any corner, including AIDS and drugs..."

Those who were born in this stage, explains (Morey, 2016) witnessed the global change, from the television with antennas and buttons to the remote control; from the presence of the family as a fundamental support, to the resounding separation. Most people of this generation are in their thirties or forties and still seek to be happy, as a great goal.

In the educational field, this generation $X$, according to (Beckhard, 2007) experienced a notable increase in university entrance, they found a learning environment that invited them to criticize the books and ideas they were taught, they were graded for questioning the ideas of other students and even those of the professor in class discussions. All of these factors contributed to the formation of leaders who shied away from the traditional commander role, which allowed us to see the emergence of a more informal, team-based leader with a willingness to share responsibilities and with a better level of communication.

"The Millennial Generation, made up of those born after 1982, is much more educated and possesses a very green conscience."

The world for them was very attractive with video games invading the screens, the Play station, the Game cube, cell phones, computers, digital cameras, among others. According to (Morey, 2016)They are lucky to be born in a world where the invention factory has already closed and it only remains to improve it to continue making it attractive and commercial. With personal postures encouraged by parents in whose generation they were mistreated, repressed and reprimanded by their parents and who are not in the disposition to deny anything to their own children.

The Y's are the children of the late Boomers and early X's, and grew up in a culture of sheltered and loved children (Zemke, Raines, \& Filipczak, 2013) characterized by the use of technology as an integral part of their lifestyle. Their affinity for the digital world is one of the most remarkable aspects of 
this group. They have grown up with the internet, smartphones, accelerated technological advances, social networks and, with these, instant information. For them, technology is not surprising, it's a no-brainer.

(Gutiérrez-Rubí, 2016). conducted a research on "The Millennials generation", where he analyzed their relationship with technology from different areas of interest in their daily lives, such as work, education, access to information or leisure activities, and presents a series of challenges and opportunities around each of these scenarios where they are increasingly influential and trend-setters.

Millennials comment (Díaz-Sarmiento, López-Lambraño, \& RoncalloLafont, 2017) they were marked by events such as the September 11 attack on the World Trade Center, the popularity of google, youtube, wikipedia, social networks like facebook and twitter, among others, the war in Iraq and Afghanistan, the Asian Tsunami, the 2008 recession, Ms. office as part of academic and working life. They are citizens of a globalized world; for them it might as well be the house next door, they want to come and go to have a multicultural experience, in many cases financed by their parents. Thanks to globalization, the characteristics of this generation are more similar across countries than those of any other generation. (Stein, 2013). They are also open to diversity at all levels.

They are not comfortable with rigid structures and demand varied and interesting positions at work. They need constant feedback and the possibility of personal and professional growth. On the family side, Millennials make up households in which the couple is active at work, so flexibility at work is one of their priorities. According to the firm's study (EYGM Limited, 2015) According to the firm's study, Millennials combine their ambition and desire for growth with the need for flexible work.

The centennials or generation $Z$, he says (Naveira, 2019) are the youngest generation group, taking over from millennials as the most digitally savvy generation. They represent a generational leap from their predecessors and are expected to be the most desirable demographic for advertisers in a few years.

The term 'centennials' was coined in 2015 by Kantar Group's consulting firm, The Future Company, to differentiate teenagers who were born in the midst of the digital boom, specifically between 1994 and 2009. Until that time they were known as Generation Z: the next after Generation Y (millennials) and Generation X. (Naveira, 2019) 
Although they share traits with millennials -both are digital natives-, it would be a mistake to consider them from the same perspective. It must be taken into account that centennials, unlike millennials, do not know life without smartphones or the Internet, and this greatly influences the way they view their existence and also the way they consume products and services.

Teachers today, according to (Valverde, Nivela, \& Espinosa, 2017), must be attentive to the innovations that are presented to facilitate the task of teaching in the classroom. The challenge is even greater when being aware that they are working with students born in the digital era, and therefore they are constantly receptive to all kinds of innovations, and that at a certain moment they may be with greater mastery of technology than the teacher himself.

Often it is not that teachers are reluctant to use technological advances, but that they have shortcomings, they do not know where and when these advances occur, they require training processes and in the best of cases, updates on technological programs that contribute to improve their work in the classroom. These teachers have in their backgrounds the realization of their training with a traditional training scheme and far from the current reality.

The ways of learning were different, because, previously, everything was written down on paper. Paper books were used, and this was perhaps the primary source of information, if not the only one. All this problem was exacerbated with the appearance of the Covid19 pandemic, which precipitated the massification of technology and forced the rapid empowerment of ICTs to face the teaching and learning process.

\section{Conclusions}

Activities related to research are very important for the advancement of knowledge, the new society is supported by the permanent and sustained development of Information and Knowledge Technologies (ICTs), which brings substantial changes to the entities that integrate them. Learning and knowledge technologies (LKTs) go beyond the mere availability of technologies and emphasize their use; an adequate use that enhances learning and teaching. The teacher, when placed in new teaching-learning environments, has the commitment to optimize his strategies supported by ICTs, which provides him with greater personal autonomy, improving his communication skills, knowledge and mastery of the tools provided by technology, which involves a paradigm shift for the teacher. 


\section{References}

Aguiar, G., \& Baute, L. M. (2020). The integration of university substantive processes from the extensionist process: a look at theory. Rev Science \& Technology, 2O(27). doi:https://doi.org/10.47189/rcct.v20i27.388

Alvarez, C. M., \& . Sierra Lombardía, V. M. (2002). Scientific research in the knowledge society. Retrieved from http://docplayer.es/31001902-La-investigacion-sociedad-delconocimiento.html

Beckhard, R. (2007). The organization of the future (MANAGEMENT). Deusto.

Carneiro, R., Toscano, J. C., \& Díaz, T. (2021). The challenges of ICT for educational change. Madrid, Spain. Retrieved from https://www.oei.es/uploads/files/microsites/28/140/lastic2.pd $\mathrm{f}$

Cañón, R., Grande de Prado , M., \& Cantón, I. (2016). Digital divide: impact on social and personal development. Associated factors. Tendencias pedagógicas, 115-132.

Díaz-Sarmiento, C., López-Lambraño, M., \& Roncallo-Lafont, L. (JulDec 2017). Understanding generations: a review of the concept, classification and distinguishing characteristics of baby boomers, $\mathrm{X}$ and millennials. Clio America, 11(22). doi:https://doi.org/10.21676/23897848.2440

Domínguez, E. L., \& Xalabarder Aulet, M. (1997). Scientific research through the Internet: the example of migratory movements in the world. Ar@cne. Internet Resources for the Social Sciences(19). Retrieved from http://www.ub.edu/geocrit/arac-19.htm

Enríquez , A., \& Sáenz, C. (2021). First lessons and challenges of the COVID-19 pandemic for SICA countries. Retrieved from https://repositorio.cepal.org/bitstream/handle/11362/46802/1 /S2100201_es.pdf

EYGM Limited. (2015). Global generations: A global study on worklife challenges across generations. Retrieved from Global generations: A global study on work-life challenges across gen: http://cs-wordpress.s3.amazonaws.com/crowdsourcev4/uploads/2015/o6/Generations-Globally-work-lifechallenges-EY-5-15.pdf

Franco, M. (2017). Articulation of the substantive functions in results of the management of linkage in the UCSG. Universidad Católica Santiago Guayaquil, Vicerectorado de Vinculación, Guayaquil. Retrieved from https://www.ucsg.edu.ec/wpcontent/uploads/pdf/vinculacion/normativas/articulacion.pdf 
Gómez, D. A., Alvarado, R. A., Martínez, M., \& Díaz de León, C. (2018). The digital divide: a conceptual review and methodological contributions for its study in Mexico. Entreciencias: Dialogues in the Knowledge Society, 6(16), 49-64. Retrieved from http://revistas.unam.mx/index.php/entreciencias.

González, J. R. (2021). De las de TIC a las TAC;una transición en el aprendizaje transversal en educación superior. Contemporary Dilemmas: Education, Politics and Values (Special edition art.23). $\quad$ Retrieved from https://www.dilemascontemporaneoseducacionpoliticayvalores .com/index.php/dilemas/article/view/2929/2932

Gutiérrez-Rubí, A. (2016). Millennials in Latin America. a perspective from Ecuador. Ecuador: Ariel.

Herrera, J. I. (2018). Contemporary research practices. The challenges of their new epistemological approaches. REv.Scientific, 3(7), 615 .

doi:https://doi.org/10.29394/Scientific.issn.25422987.2018.3.7.0.6-15

IBERDROLA. (2021). The digital divide in the world and why it causes inequality. Retrieved from https://www.iberdrola.com/compromiso-social/que-es-brechadigital

Licona, K., \& Veytia Bucheli , M. (2019). Training in and for research and the use of Information and Communication Technologies. Athens, 2(46). Retrieved from https://www.redalyc.org/journal/4780/478060100005/html/

Martínez, A., \& Ríos Rosas, F. (2006). Epistemology and Paradigm, as a Differential Basis in the Methodological Orientation of the Degree Work. Moebio Tape, 111-121. Retrieved from https://www.redalyc.org/articulo.oa?id=10102508

Matos, E., \& Cruz, L. (2017). Research in higher education institutions as an integrated substantive process: its endogenous challenge.

REv Pedagogical Sciences and Innovation, 5(3). doi:https://doi.org/10.26423/rcpi.v5i3.212

Morey, S. (16 June 2016). National University of the Peruvian Amazon. Retrieved from Los cambios generacionales y nuestra realidad:

https://www.unapiquitos.edu.pe/contenido/opiniones/Loscambios-generacionales-y-nuestra-realidad.html

Naveira, A. (October 21, 2019). This is what centennials are like: the generation that is revolutionizing the way we do marketing... and sell. Retrieved from Marketing e Commerce: https://marketing4ecommerce.net/los-centennials-lageneracion-digital-mas-experta-la-historia/ 
Ortiz, A., Pérez, M., \& Velázquez, R. (2015). Procedure for qualityoriented integrated process management. Application in the university of Holguin. Congreso Universidad, IV No2. Retrieved from

http://www.congresouniversidad.cu/revista/index.php/congres ouniversidad/index

Pérez, C. (2004). Revoluciones tecnológicas y capital financiero. Mexico: Revoluciones tecnológicas y capital financiero. Retrieved from https://eva.fing.edu.uy/pluginfile.php/309314/mod_resource/ content/2/P\%C3\%A9rez\%2C\%2BCarlota-Revoluciones-

Tecnologicas-y-Capital\%2Bfinanciero.compressed.pdf

Pérez, R., Mercado, P., Martínez, M., Mena, E., \& Partida, J. Á. (2018). The knowledge society and the information society as the cornerstone in educational technological innovation. RIDE Revista Iberoamericana Para La Investigación Y El Desarrollo $\begin{array}{lllll}\text { Educativo, } & 8(16), & 847 & - & 870 .\end{array}$ doi:https://doi.org/10.23913/ride.v8i16.371

Rivera, C. G., Espinosa, J. M., \& Valdés, Y. D. (2017). Scientific research in Ecuadorian universities. Priority of the current educational system. Rev. Cubana Edu. Superior, 36(2), 113-125. Obtenido

de http://scielo.sld.cu/scielo.php?script=sci_arttext\&pid=So25743142017000200011

Romero, M. S. (2017). Academic work in the construction of knowledge: between doing and discourse in teacher education. RIDE. Rev. Iberoam. Research. Desarro. , 735-752. Retrieved from

http://www.scielo.org.mx/scielo.php?script=sci_arttext\&pid=S 2007-74672017000200735

Samá, D., \& Cruz Álvarez, Y. (JAN-JUL 2018). Quality of substantive processes. The postgraduate process. Revista Estrategia $y$ Gestión Universitaria, 6(1), 43-61. Retrieved from https://core.ac.uk/download/pdf/287219916.pdf

Sandia, B. E., Luzardo, M., \& Aguilar-Jiménez, A. S. (2019). Appropriation of Information and Communication Technologies as Generators of Educational Innovations. Science, Teaching and Technology, 3o(58), 267-289. Retrieved from https://www.redalyc.org/journal/145/14560146013/html/

Skolimowski, H. (16 November 2016). El País. We were born in difficult times. Obtenido de https://elpais.com/cultura/2016/11/14/babelia/1479128088_6 09922.html 
Stein, J. (9 May 2013). Millennials: The Me Me Me Me Generation. Retrieved from http://content.time.com/time/subscriber/article/o,33009,2143 oo1,oo.html

Tablado, F. (2021). Digital divide. Definition, causes and consequences. Atico34 Group. Retrieved from https://protecciondatos-lopd.com/empresas/brecha-digital/

Valverde, M., Nivela, A., \& Espinosa Izquierdo, J. G. (2017). Teachers and students, the digital generation gap. Espirales, 1(7), 64-78. doi:https://doi.org/10.31876/re.v1i7.228

Van Dijk, J. A., \& Van Deursen, A. (2014). Digital skills: unlocking the information society. (P. M. Ltd., Ed.) New York, USA. Retrieved from https://research.utwente.nl/en/publications/digitalskills-unlocking-the-information-society

Zemke, R., Raines, C., \& Filipczak, B. (2013). Generations at work: managing the clash of boomers, Gen $X$ and Gen $Y$ in the workplace. New York: American Management Association. 